\title{
Area Search Warrants in Border Zones: Almeida-Sanchez and Camara
}

The illegal entry of aliens into the United States is a significant national problem. Hundreds of thousands of illegal aliens annually enter this country. ${ }^{1}$ Although the federal government can inspect everyone coming into the United States to determine their citizenship, ${ }^{2}$ this procedure has not succeeded in eliminating the problem. In order to stem the flow of illegal aliens, the government has extended its alien checking operations to points removed from the border. In Almeida-Sanchez v. United States, ${ }^{3}$ the Supreme Court for the first time addressed the question of Fourth Amendment protection accorded travelers near but not at the border.

Unfortunately, Almeida-Sanchez did not end the uncertainty concerning Fourth Amendment standards for nonborder alien searches. ${ }^{\ddagger} \mathrm{A}$

1. More than a half million of these aliens were apprehended in 1972.1972 IMMIGRAtion \& NAtUralizition Service (INS) ANN. Rep. 7. In 1973, the figure exceeded 650,000. 1973 INS ANN. REP. 8. Most of these aliens ( 88 percent) entered over the Mexican border. Id.

2. At the border, neither a warrant nor probable cause is necded to Iegitimize the search. See United States v. Almeida-Sanchez, 452 F.2d 459, 461 (9th Cir. 1971) (Browning, J., dissenting), rev'd, 413 U.S. 266 (1973); Marsh v. United States, 344 F.2d 317, 324 (5th Cir. 1965); United States v. Becker, 347 F. Supp. 1039, 1042 (D. Mass. 1972); Note, Border Searches and the Fourth Amendment, 77 YALE L.J. 1007, 1008 (1968).

3 . 413 U.S. $266(1973)$. See Note, The Aftermath of Almeida-Sanchez v. United States: Automobile Searches for Aliens Take on a New Look, 10 Calif. W.L. Rrv. 657 (1974); The Supreme Court, 1972 Term, 87 HARv. L. Rev. 1, 196 (1973); 51 J. URman L. 556 (1974); Comment, Extended Border Searches and Probable Cause: Almcida-Sanchez v. United States, 1973 W.Asti. U.L.Q. 889.

4. Two basic issues with respect to Almeida-Sanchez remain unsettled. One of these is the scope of the decision, the other is retroactivity. It is unclear whether AlmeidaSanchez invalidated all border patrol traffic checking operations conducted away from the border without probable cause, or only roving searches so conducted. The Ninth Circuit has concluded that all such operations are governed by Almeida-Sanchez, including checkpoint scarches. Unitcd States v. Bowen, $500 \mathrm{~F} .2 \mathrm{~d} 960$ (9th Cir. 1974), cert. granted, 13 U.S.L.W. 3208 (U.S. Oct. 9, 1974) (No. 73.6848). In addition, there is disagreement over whether Almeida-Sanchez applies only to searches conducted under 8 U.S.C. $\$ 1357$ (a)(3) (1970), or whether it also affects the interrogation power granted to the border patrol by id. $\$ 1357(a)(1)$. The Ninth Circuit has held that $\$ 1357(a)(1)$ is limited by AlmeidaSanchez. United States v. Brignoni-Ponce, 499 F.2d Il09 (9th Cir. 1974), cert. granted, 43 U.S.L.W. 3208 (U.S. Oct. 9, 1974) (No. 74-114). That decision creates a conflict among the circuits. Compare id., with United States v. Bowman, 487 F.2d 1229((10th Cir. 1974) (\$ 1357(a)(1) interrogation power is unaffected by Almeida-Sanchez).

The retroactive application of Almeida-Sanchez is also uncertain. The Ninth Circuit ipplied Almeida-Sanchez retroactively to roving scarches, but gave it prospective effect in cases involving searches conducted at fixed checkpoints. Compare United States v. Peltier, 500 F.2d 985 (9th Cir. 1974), cert. granted, 43 U.S.L.W. 3280 (U.S. Nov. II, 1974) (No. 73-2000) (retroactivity for roving searches), with United States v. Bowen, 500 F.2d 960 (9th Cir. 1974), cert. granted, 43 U.S.L.W. 3208 (U.S. Oct. 9, 1974) (No. 73-6848) (prospective application to checkpoint searches). Bowen accords with the Fifth Circuit's decision in United States v. Miller, 492 F.2d 37 (5th Cir. 1974). However, the Ninth Circuit appears to have reversed itself by giving Bowen retroactive application. United States v. 
major problem with the decision is the lack of consensus on the Court concerning the applicable Fourth Amendment requirements. ${ }^{5} \mathrm{Al}$ though joining the majority opinion in Almeida-Sanchez, Justice Powell also filed a concurring opinion in which he proposed a Fourth Amendment analysis based on the administrative inspection model of Camara v. Municipal Court. ${ }^{6}$ The Almeida-Sanchez concurrence was endorsed by the four dissenters as well as an undesignated number of the other Justices. ${ }^{7}$ Thus, Justice Powell's concurrence has the support of a majority of the Court and may become law in a future case.

The issue posed by the Almeida-Sanchez concurrence is not a narrow question of border patrol power in the region adjacent to the Mexican border. The appropriate sections of Title 8 and the Code of Federal Regulations define the ambit of Immigration and Naturalization Service (INS) authority as 100 air miles inland from any external border of the United States. ${ }^{8}$ In addition to the Mexican border, searches of the type proposed by the Almeida-Sanchez concurrence

Ortiz (9th Cir. June 19, 1974), cert granted, 43 U.S.L.W. 3208 (U.S. Oct. 9, 1974) (No. 73-2050).

As noted in United States v. Baca, 368 F. Supp. 398, 408 (S.D. Cal. 1973): "Since Almeida-Sanchez,... this area of the law has been characterized by extreme instability." See generally Note, Extended Border Searches by Immigration Officers: United States v. Thompson, 13 Colum. J. Transnat'l L. 143, 151-52 (1974); 27 Vand. L. Rev. 523 (1974).

5. Justice Stewart delivered the opinion of the Court, in which Justices Douglas, Brennan, Marshall, and Powell joined. Justice Powell filed a concurring opinion. Justice White filed a dissenting opinion, in which Chief Justice Burger and Justices Blackmun and Rehnquist joined.

6. 387 U.S. 523 (1967).

7. 413 U.S. at 270 n.3. This observation has been expressed by law review commentary. See The Supreme Court, 1972 Term, 87 HARv. L. REv. 1, 196 (1973). The INS has noted the significance of Almeida-Sanchez:

In a concurring opinion Mr. Justice Powell indicated his belief that a judicial officer would issue a warrant for a roving search on a particular road or roads for a reasonable period of time. Since this view was approved by the four dissenting Justices, and by an undesignated number of the other Justices, the so-called area search warrant' apparently is supported by a majority of the Supreme Court.

1973 INS ANN. REP. 16.

8. With respect to powers of the INS, 8 U.S.C. $\$ 1357(1970)$ provides:

(a) Any officer or employee of the Service authorized under regulations prescribed by

the Attorney General shall have power without warrant-

(1) to interrogate any alien or person believed to be an alien as to his right to be or to remain in the United States;

$\cdots$

(3) within a reasonable distance from any external boundary of the United States, to board and search for aliens any vessel within the territorial waters of the United States and any railway car, aircraft, conveyance or vehicle, and within twenty-five miles from such external boundary to have access to private Iands. but not dwellings, for the purpose of patrolling the border to prevent illegal entry of aliens into the United States; and

(4) to make arrests for felonies which have been committed and which are cognizable under any law of the United States regulating the admission, exclusion, or expulsion of aliens....

The Attorney General has authorized Border Patrol agents to act as Immigration officers, 8 C.F.R. \$ 103.1(i) (1974). The "reasonable distance" mentioned in $\$ 1357$ (a)(3) is 100 air miles. 8 C.F.R. \$287.1 (1974). 
could occur anywhere within 100 air miles of the Canadian border or the Atlantic, Pacific or Gulf coasts, or the perimeters of Alaska and Hawaii. Upon a proper showing, the INS might obtain area warrants to search any and all vehicles on any roads within such border zones. Probable cause or even reasonable suspicion to believe that any particular vehicle contained illegal aliens would be irrelevant.

Envisioning such a broad scope of INS activity is not idle speculation. The INS has announced efforts to augment its alien detection operations in areas removed from the Mexican border, particularly in urban areas where aliens congregate. ${ }^{9}$ Moreover, area searches could conceivably be employed as a tactic in pursuit of targets other than illegal aliens.

The possible creation of a Fourth Amendment free-fire zone around the United States, and the continuing relevance of Almeida-Sanchez for pending cases, ${ }^{10}$ require that the Powell concurrence be closely scrutinized. This Note contends that the analogy between alien searches in border zones and administrative inspections is unpersuasive, so that procedures which render administrative inspections constitutional fail to justify alien searches. Part I will outline the majority opinion and the concurrence in Almeida-Sanchez. Part II will distinguish that case from Camara, thereby demonstrating the inapplicability of Camara's administrative search rationale to the situation of roving alien searches in Almeida-Sanchez.

\section{Almeida-Sanchez}

On April 30, 1970, federal officers stopped Condrado AlmeidaSanchez as he drove on Route 78 in southern California. Although they had neither probable cause nor a warrant, ${ }^{11}$ the officers, acting in their capacity as border patrol agents of the INS, ${ }^{12}$ searched the car in an effort to find illegal aliens.

Although no aliens were uncovered, discovery of a cache of marijuana under the rear seat of the car served as probable cause to conduct a thorough vehicular search, which netted 73 kilograms of the

9. Concerning their area control programs, the INS reported:

Again in 1972 an increasing number of aliens in illegal status was located in the interior areas of the United States. To meet the need for intensified controls in this vital area of operational concern, investigative area control forces were significantly strengthened in most of the major urban areas of the nation.

1972 INS ANN. REP. 8.

10. See note 4 supra.

11. 413 U.S. at 268.

12. See note 8 supra. 
illegal drug. ${ }^{13}$ Almeida-Sanchez was later convicted of concealing and transporting illegally imported marijuana. ${ }^{14}$ On appeal, the Ninth Circuit affirmed the conviction, ruling that the search had been legal. ${ }^{15}$

The United States Supreme Court reversed the court of appeals and held that without consent or probable cause, the warrantless search violated the defendant's Fourth Amendment rights. The Court considered and rejected four possible justifications for the initial search of Almeida-Sanchez's car. Because the federal agents did not have probable cause, the search was not justifiable within the special Fourth Amendment doctrine for automobile searches. ${ }^{16}$ Neither was it a border search. At the time of his arrest, Almeida-Sanchez was 25 miles from the Mexican border, on a road that neither crossed the border nor came closer to it than 20 miles. ${ }^{17}$ Moreover, because there was neither a warrant nor consent, the search was held not to qualify as a valid administrative inspection. ${ }^{18}$

Eliminating these grounds of support for the search of Almeida-Sanchez's car, the Court's only remaining consideration was the statute empowering the INS to search. ${ }^{19}$ The Court, stating that any other

13. See United States v. Almeida-Sanchez, 452 F.2d 459 (9th Cir. 1971), rev'd, 413 U.S. 266 (1973).

14. Act of July 18, 1956, ch. 629 , 70 Stat. 570 (now repealed).

15. United States v. Almeida-Sanchez, 452 F.2d 459 (9th Cir. 1971). See Note, Border Search in the Ninth Circuit: Almeida-Sanchez-A Borderline Decision, 23 Hastings L.J. 1309 (1972).

16. The automobile search doctrine originated in Carroll v. United States, 267 U.S. 132 (1925). In general, it permits a warrantless search of a car "where it is not practicable to secure a warrant because the vehicle can be quickly moved out of the locality or jurisdiction in which the warrant must be sought." Id. at 153. However, as Justice Stewart wrote in Almeida-Sanchez, Carroll "does not declare a field day for the police in searching automobiles. Automobile or no automobile, there must be probable cause for the search." 413 U.S. at 269. See generally Note, Warrantless Searches and Seizures of Automobiles, 87 HARv. L. REv. 835 (1974).

17. 413 U.S. at 267-68. Moreover, the search did not take place at a functional equivalent of the border. As defined in the majority opinion, a functional equivalent of the border is any place where it is reasonably certain that all persons present have just entered the United States. For example, one type of functional equivalent is an intersection "marking the confluence of two or more roads that extend from the border...." Id. at 273. In this example, the absence of local traffic makes it reasonable for the government to exercise the full power to search associated with the border itself. In Almeida-Sanchez the road on which petitioner was stopped never crossed the border, and therefore the requisite nexus was lacking.

18. The government had relied on Camara v. Municipal Court, 387 U.S. 523 (1967), Colonnade Catering Corp. v. United States, 397 U.S. 72 (1970), and United States v. Biswell, 406 U.S. 311 (1972), to establish their contention that an alien search was an administrative inspection and hence did not require probable cause or a warrant. However, Justice Stewart found no support for the government in those cases. Under Camara, a valid administrative search requires either a warrant or consent. Colonnade in. volved the sale of liquor and Biswell concerned the sale of guns, so both pertained to a governmentally regulated business; in such a business, the proprietor, in obtaining permission to enter the regulated field, implicitly gives his consent to be inspected by the government. See 413 U.S. at 270-71.

19. 8 U.S.C. $\$ 1357$ (a) (1970) (for text of this section, see note 8 supra.) 
interpretation would render the statute unconstitutional, construed the Act to mean that the power to search without a warrant was limited to cases where there was probable cause or consent to search. ${ }^{20}$ Because there had not been probable cause, consent, or a warrant, Almeida-Sanchez's conviction was reversed.

Justice Powell concurred in the reversal of the conviction and joined the majority opinion. He also filed a concurring opinion in which he attempted to harmonize the government's need to search with the individual's right of privacy. Basing his approach on Camara v. Municipal Court, ${ }^{21}$ he sought to fashion a procedure whereby future roving alien searches might be rendered constitutional.

Justice Powell's analysis involved two parts. The first was an inquiry into "whether some functional equivalent of probable cause may exist for the type of search conducted in this case."22 Camara established three criteria for determining whether a particular search might be conducted upon some showing less than strict probable cause. These criteria were a history of judicial and public acceptance of the type of search, the need to conduct this search in light of alternatives available to protect the governmental interest, and the limited intrusiveness of the search upon the individual's privacy. ${ }^{23}$ Justice Powell took judicial notice of the acceptance of roving auto searches by the Courts of Appeals for the Ninth and Tenth Circuits, where the problem of illegal aliens is most serious. Need to conduct the search was established by the government's showing that no alternative was reasonably possible. Finally, Justice Powell advanced three reasons for concluding that roving searches for aliens were only modest impositions on individual privacy. First, most illegal aliens apprehended in the United States are deported rather than prosecuted, which evidences a nonprosecutorial intent on the part of the government. Second, these searches are incidental to protection of the border, and therefore some of the special qualities of border searches inhere in roving alien searches. Third, searches of automobiles are inherently less intrusive than searches of people or buildings. Thus, concluding that Camara's criteria were met by roving alien searches, Justice Powell

20. 413 U.S. at 273.

21. 387 U.S. $523(1967)$.

22. 413 U.S. at 277. "Functional equivalent" of probable cause is the term Justice Powell assigned to the justification found by the Camara Court for conducting administrative inspections. Analogous to the stricter requirement of traditional probable cause to conduct a search for evidence of a crime, "functional equivalent" is the Fourth Amendment standard upon which a search warrant may be based in the context of an administrative inspection.

23. 387 U.S. at 537 . See 413 U.S. at 278. 
decided that there could be a functional equivalent of probable cause to conduct such searches. ${ }^{24}$

Having affirmatively answered the first Camara inquiry, Justice Powell next considered whether a warrant was needed. Camara held that "except in certain carefully defined classes of cases, a search of private property without proper consent is 'unreasonable' unless it has been authorized by a valid search warrant." 25 In an administrative inspection, a warrant is required unless there would be such difficulty in obtaining it that the governmental purpose would be frustrated. ${ }^{20}$ The Almeida-Sanchez concurrence, following Camara, decided that a warrant is required for a roving alien search. ${ }^{27}$

\section{Almeida-Sanchez and Camara Distinguished}

\section{A. Camara v. Municipal Court}

Roland Camara refused to permit municipal housing inspectors to enter his residence. This refusal violated a municipal ordinance, and Camara was convicted of that offense. The United States Supreme Court reversed his conviction, holding that a warrantless search by building inspectors violated the Fourth Amendment. ${ }^{28}$ In deciding Camara, the Court overruled its earlier decision in Frank v. Maryland, ${ }^{29}$ which held such inspections to be constitutional, even though conducted without search warrants.

In ruling that the Fourth Amendment did not require search warrants in this situation, Frank reasoned that administrative searches

24. 413 U.S. at $278-79$.

25. 387 U.S. at $528-29$.

26. Id. at 533 .

27. 413 U.S. at $279-85$. The governmental purpose would not be frustrated, Justice Powell reasoned, because roving searches were always planned in advance. Id. at 283. Moreover, the problem of obtaining a warrant to search a moving object, such as all auto, was not present here, because the information needed to procure an area search warrant would concern "obviously non-mobile sections of a particular road or area embracing several roads." Id. at 282. Justice Powell suggested several factors relevant in deciding whether a showing of probable cause has been made:

(i) the frequency with which aliens illegally in the country are known or reasonably

believed to be transported within a particular area;

(ii) the proximity of the area in question to the border;

(iii) the extensiveness and geographic characteristics of the area, including the roads therein and the extent of their use, and

(iv) the probable degree of interference with the rights of innocent persons, taking into account the scope of the proposed search, its duration, and the concentration of illegal alien traffic in relation to the general traffic of the road or area.

Id. at 283-84 (footnote omitted).

28. Camara v. Municipal Court, 387 U.S. 523 (1967). For an insightful analysis of Camara, see La Fave, Administrative Searches and the Fourth Amendment: The Camara and See Cases, 1967 Sur. Cr. REv. 1.

29. 359 U.S. 360 (1959), overruled, Camara v. Municipal Court, 387 U.S. 523 (1967). 
were of a special kind. No evidence of crime was sought, no other means were available to promote the public health, safety and welfare, and the type of search in question had historically been an accepted practice. ${ }^{30}$ Camara conceded these points but, rather than accepting Frank's conclusion that they excused building inspections from the warrant requirement of the Fourth Amendment, considered them in determining the reasonableness of the search. ${ }^{31}$ Borrowing from Justice Douglas's dissent in Frank, the Court in Camara decided that a constitutionally permissible housing inspection need not be based on information concerning any particular building, but instead could be justified on an assessment of the conditions in the neighborhood at large. ${ }^{32}$ Appropriate factors to consider include the age, nature, occupancy and ownership of the building, the time elapsed since the last inspection, and the general condition of the area. Upon evaluating the data presented by the agency seeking the warrant, the magistrate would decide if the program of administrative searches was reasonable. ${ }^{33}$ Camara envisioned primary reliance on the individual's consent, however, with resort to warrants only after entry was denied. ${ }^{34}$

\section{B. The Almeida-Sanchez Search Does Not Fit the Camara Model}

To determine if the Almeida-Sanchez concurrence is supported by Camara requires an examination of the threshold question of whether there can be a functional equivalent of probable cause for random roving alien searches. Application of Camara's three criteria of history, need, and limited intrusiveness demonstrates that random roving alien searches are not searches for which a functional equivalent of probable cause can exist.

\section{History of Judicial Acceptance}

Justice Powell's concurrence in Almeida-Sanchez relied upon a history of judicial acceptance of roving alien searches as support for his conclusion that there could be a functional equivalent of probable cause. However, that history is significantly different from the tradition of judicial responses to building inspections that the Court considered in Camara. Almeida-Sanchez was decided by the Court only 27 years after the statutory authority for INS roving alien searches had

30. 359 U.S. at $366-67,371-72$.

31. 387 U.S. at 531-34.

32. Id. at 535, 536, 538 .

33. Id. at 538 .

34. Id. at $539-40$. 
been created. ${ }^{35}$ During that period, only a very few cases in the Ninth and Tenth Circuit Courts of Appeals had explicitly approved alien searches conducted away from the border without probable cause. ${ }^{39}$ The first time it considered the question, the Court held that such searches were unconstitutional. Although the prior circuit court approval of these searches is technically a history of judicial acceptance, it is insignificant in comparison with the history supporting the Camara court. Camara involved a practice that not only had been accepted for more than 150 years, ${ }^{37}$ but also had been previously upheld by the Court in Frank v. Maryland. In making historical acceptance one criterion of reasonableness, the Camara Court had before it a longer and more authoritative history than the brief record of lower court approval considered persuasive by the Almeida-Sanchez concurrence. Properly viewed, the majority opinion in Almeida-Sanchez conforms this area to traditional Fourth Amendment doctrine, with the prior history of random roving alien searches constituting a brief aberration from that tradition. ${ }^{38}$

\section{Need to Conduct the Search}

The second criterion the Almeida-Sanchez concurrence applied to random roving alien searches was the need to conduct the search. Justice Powell defined "need" as "the absence of other methods for vindicating the public interest ...."39 The concurrence did not consider or evaluate any alternatives. Rather, it found that the government had made "a convincing showing . . . that roving checks of automobiles are the only feasible means" of apprehending certain classes of border crossers. ${ }^{40}$ An examination of its brief in AlmeidaSanchez reveals that the government also failed to suggest or evaluate

35. 8 U.S.C. $\$ 1357$ (a) (1970) had its origin in the Immigration and Nationality Act of 1946, ch. 768, $\$ 287$ (a), 60 Stat. 865. See Brief for Appellee at 20-21, Almeida-Sanchez $v$. United States, 413 U.S. 266 (1973).

36. See United States v. Almeida-Sanchez, 452 F.2d 459, 464 (9th Cir. 1971) (Browning, J., dissenting). Judge Browning noted that the Ninth, and possibly the Tenth, Circuits were alone among the courts of appeals in failing to impose on the INS a requirement of probable cause for nonborder alien searches. Moreover, the period of judicial acceptance of these searches was quite brief; Judge Browning noted that until 1963, even the Ninth Circuit required probable cause to conduct alien searches that were not border searches. Id. at $464 \mathrm{n} .8$. However, as Judge Browning implied, a major difficulty in analyzing circuit court decisions in this area is that their use of an elastic border concept tended to draw many alien searches not conducted at or near the border into the rubric of "border search." Talismanic use of the word "border" often justified searches made without probable cause.

37. 387 U.S. at 537.

38. United States v. Peltier, 500 F.2d 985, 988 (9th Cir. 1974), cert. granted, 43 U.S.L.W. 3280 (U.S. Nov. 11, 1974) (No. 73-2000).

39. 413 U.S. at 278 (Powell, J., concurring).
40. Id. at 276. 
any alternatives to the roving auto search. ${ }^{41}$ Instead, the brief merely stated that such operations were "essential" to INS enforcement programs. ${ }^{42}$ In fact, it is likely that reasonably possible alternatives do exist. As one example, the majority opinion suggested the use of fixed checkpoints at border "equivalents." 43

Justice Porvell's discussion of the absence of alternatives does not indicate any serious questioning into the assertions of the government. Rather, the government's lack of proof and the concurrence's onesentence treatment of the issue reveal that the questions of real pertinence to the problem at hand were virtually ignored. Although following the analytic form of Camara, the Almeida-Sanchez concurrence did little to solve the substantive problems raised by the application of Camara to roving alien searches.

\section{Limited Intrusion upon Individual Privacy}

The third area of inquiry in the Almeida-Sanchez concurrence concerned the invasion of privacy entailed by roving auto search.

41. The government should have the burden of proving the existence of an exceptional situation when it seeks a modification of Fourth Amendment procedures; $c f$. United States v. United States District Court, 407 U.S. 297, 324.25 (1972) (Douglas, J., concurring); Vale v. Louisiana, 399 U.S. 30 (1970) (government sought power to search dwelling without search warrant). Accord, Chimel v. California, 395 U.S. 752, 762 (1969); United States v. Jeffers, 342 U.S. 48, 51 (1951); McDonald v. United States, 335 U.S. 45I, $456(1948)$. It is reasonable to place the burden of proof on the government, because the government may be regarded as the moving party in seeking a modification of Fourth Amendment standards. Moreover, the government will probably also be the party best able to offer evidence as to the existence of an exceptional circumstance. See generally C. McConmick, Evidence $\$ 337$, at $785-89$ (E. Cleary ed. 1972). In such cases, it would be unreasonable to require a defendant to prove that he was entitled to the protection of the Fourth Amendment.

12. See Brief for Appellee at 21-27, Almeida-Sanchez v. United States, 413 U.S. 266 (1973). It should be noted that all traffic checking operations combined produced considerably less than 10 percent of the total number of deportable aliens located by the INS in 1972. Id. at 26. See note 1 supra. Fixed and temporary checkpoints, as well as roving searches contributed to this number. $I d$. at 23-26. No effort was made by the government to allocate percentages of the total to each of the traffic checking operations. "Need" to conduct roving alien scarches should properly be defined with respect to the availability of reasonable alternatives for detecting the fraction of 10 percent of all deportable alicns attributable to roving alien searches. When so viewed, the government's need to conduct these searches is markedly less significant.

43. 413 U.S. at 273 . See note 17 supra. The government was operating only 13 fixed chechpoints at the time of the search of Almeida-Sanchez. Brief for Appellee at 24, Almeida-Sanchez v. United States, 413 U.S. 266 (1973). It was not indicated whether these checkpoints werc at functional equivalents.

Another alternative is also feasible. If search without probable cause is permitted at functional equivalents of borders, then random roving searches without probable cause should be equally permissible at any point between the border and the farthest point inland that could be construed to be a functional equivalent. Although no fixed distance could be established, the permissible range of such a search would be from the border either to the nearest road that does not cross the border or to the nearest habitation on the United States side, whichever is closer to the border.

This suggestion clearly does not exhaust the possible alternatives available to the INS, or to the Court, for dealing with the problem of illegal alien traffic. It is included merely as a contrast to the cursory consideration of need presented by the AlmeidaSanchez concurrence. 
Camara held that if a search was nonpersonal and not aimed at discovery of evidence of a crime, then it was only modestly intrusive.4 Justice Powell's Almeida-Sanchez concurrence advanced three reasons for finding the random roving alien searches only modestly intrusive. These were the absence of prosecutorial intent, the density of alien traffic combined with proximity to the border, and the inherently less intrusive quality of auto searches.

First, the concurrence found that prosecutorial intent did not underlie the random roving alien searches. However, the phrase "prosecutorial intent," as used in the Almeida-Sanchez concurrence, is misleading. ${ }^{45}$ As noted above, Camara considered a search to be a limited invasion of Fourth Amendment privacy when it was not aimed at discovering evidence of a crime. The building code inspections considered in Camara were of this type because the municipal code did not make the existence of a building code violation punishable per se. Rather, prosecution could only be based either on a failure to correct conditions uncovered during the inspection, or, as in Camara itself, on refusal to permit inspectors to enter. ${ }^{46}$ Therefore, detection of building code violations was not discovery of evidence of a crime. On the other hand, it is a federal crime to enter the country illegally or to aid an illegal entrant. ${ }^{47}$ Thus, the discovery by INS

44. 387 U.S. at 537 .

45. Moreover, the concurrence seems internally inconsistent; notwithstanding the conclusion that there did not exist prosecutorial intent, it characterized the government's information upon which a decision to search was based as relating "to criminal activity in certain areas." 413 U.S. at 281 (Powell, J., concurring).

46. Although $\$ 507$ of the San Francisco Building Code is ambiguous, it is clear that the Camara Court assumed that this section did not impose a criminal penalty solely because of the existence of violations. The Court noted that the prevailing procedure for enforcing building codes, such as the one in Camara, involved as an initial matter the issuance of an administrative compliance order; it is the failure to obey this order, and not the existence of code violations, that is the criminal offense. 387 U.S. at 531 \& nn.8-9. The only exception to this general rule cited by the Court was a New York City code provision. Id. at 531 n.7. Significantly, the Court did not cite $\$ 507$ of the San Francisco Building Code as another exception to the general rule. It was therefore possible for the Court later to regard a search under the San Francisco ordinance as only a limited intrusion upon the citizen's privacy because it was not aimed at the discovery of evidence of a crime.

The Court's treatment of the San Francisco Code provision leaves unanswered the question of whether the decision would have been different if the case had arisen under the New York code. Moreover, the interpretation of Camara presented in this Note sug. gests that the Court erred in United States v. Biswell, 406 U.S. 311 (1972), in relying upon Camara's administrative inspection rationale in the context of a search for evidence of a violation of the Federal Gun Control Act of Oct. 22, 1968, Pub. L. No. 90-618, 82 Stat. 1213.

47. 8 U.S.C. $\$ 1325(1970)$ provides:

Any alien who (1) enters the United States at any time or place other than as designated by immigration officers, or (2) eludes examination or inspection by immigration officers, or (3) obtains entry to the United States by a willfully false or misleading representation or the willful concealment of a material fact, shall, for the first com- 
agents that a person either is an illegal alien or is transporting illegal alien passengers is the discovery of evidence of a crime. The traffic checking operations at issue in Almeida-Sanchez were directed at discovering such evidence, and therefore should fail the Camara test.

If there are to be any principled and intelligible bounds on the doctrine of administrative searches, Camara's requirement that the search not be directed at discovering evidence of a crime should be interpreted to refer to the express statutory language. The AlmeidaSanchez concurrence injected a new element into the Camara test by substituting the subjective prosecutorial intent of the government in place of the explicit wording of the statute. The issue of subjective prosecutorial intent is not relevant in the context of a search for evidence of a crime, and traditional probable cause must be established to validate such a search.

The concurrence also suggested that a low prosecution rate indicates administrative rather than prosecutorial intent. ${ }^{48}$ However, even assuming that the concept of subjective prosecutorial intent is meaningful and relevant here, the use of this low prosecution rate is misleading when considered independently of data on the rate of convictions and magnitude of the illegal alien traffic. The concurrence infers that the government has little desire to prosecute these of fenses; from a three percent prosecution figure, however, it is equally inferrable that immigration cases are difficult to prosecute, and prosecutions are limited to cases in which a conviction is relatively certain. Alternatively, if the cases are not complex and convictions are relatively easy for the government to obtain, the low prosecution rate may reflect a constraint imposed on the government by limited manpower and resources relative to the number of illegal aliens apprehended. The latter inference is at least as likely as nonprosecutorial intent; more than 390,000 deportable aliens were located in fiscal $1972,4^{40}$ of whom 12,799 were prosecuted, ${ }^{50}$ and the conviction rate

mission ... be guilty of a misdemeanor ... and for a subsequent commission ... shall be guilty of a felony ....

8 U.S.C. $\$ 1324(a)(1970)$ provides:

Any person,.... who-

(1) brings into or lands in the United States...

(2) knowing that he is in the United States in violation of law..., trans-

ports, or moves, or attempts to transport or move...

(3) willfully or knowingly conceals, harbors, or shields from detection ...

(4) willfully or knowingly encourages or induces,... the entry into the United States of-

any alien ... not duly admitted by an immigration officer... shall be guilty of a felony .....

48. 413 U.S. at 278.

49. Id. at 294 (White, J., dissenting). This figure is understated. See note 1 supra.

50. 1972 INS ANN. REP. 121. 
in these cases was almost 94 percent.51 Although the percentage of prosecutions is low, both the absolute number of aliens prosecuted and the conviction rate are very substantial. Thus, the inference of subjective nonprosecutorial intent offered by the Almeida-Sanchez concurrence is inconclusive at best.

Further, if the issue of subjective intent is relevant at all to this problem the Court should consider the possibility of abuse inherent in using a less stringent standard of probable cause for roving alien searches. These searches might be used as a pretext for dragnets aimed at the discovery of a wide variety of crimes in which strict probable cause to search has traditionally been required.52

The second idea in support of Justice Powell's conclusion that roving alien searches are only modestly intrusive concerned the density of illegal aliens present in the search area and the proximity of that area to the border. As in its discussion of the criterion of "need," the Almeida-Sanchez concurrence accepted the government's statement that

51. Id. Of the 12,799 aliens prosecuted in $1972,12,018$ were convicted, resulting in a conviction rate of 93.8 percent.

52. Both judges and commentators have noted the problems, including police perjury, of searches conducted on various pretexts inconsistent with good faith or constitutional procedures. See United States v. Legato, $480 \mathrm{F.2d} 408,414$ (5th Cir.), cert. denied, 414 U.S. 979 (1973); Williams v. Adams, 436 F.2d 30, 38 (2d Cir. 1970), rev'd, 407 U.S. 143 (1972); Younger, The Perjury Routine, 204 Nation 596, 597 (1967); Note, Police Perjury in the Narcotics "Dropsy" Cases: A New Credibility Gap, 60 GEo. L.J. 507 (1971); Note, In Search of the Border: Searches Conducted by Federal Customs and Immigration Officers, 5 N.Y.U.J. INT'L L. \& PoL. 93, 106 (1972) [hereinafter cited as In Search of the Border]. Although not conclusive on the issue of police pretense or perjury, it is nevertheless instructive to recognize that most challenges to the legitimacy of border patrol action have involved marijuana convictions arising from alien searches. See, e.g., United States v. Phillips, 496 F.2d 1395 (5th Cir. 1974); United States v. Nevarez-Alcantar, 495 F.2d 678 (10th Cir. 1974); United States v. Martinez-Miramontes, 494 F.2d 808 (9th Cir. 1974); United States v. McKim, 487 F.2d 305 (5th Cir, 1973); United States v. Bowman, 487 F.2d 1229 (10th Cir. 1973); United States v. Maddox, 485 F.2d 361 (10th Cir. 1973); United States v. Byrd, 483 F.2d 1196 (5th Cir. 1973), aff'd on rehearing, 494 F.2d 1281 (5th Cir. 1974); United States v. Thompson, 475 F.2d 1359 (5th Cir. 1973); United States v. McDaniel, 463 F.2d 129 (5th Cir. 1972), cert. denied, 413 U.S. 919 (1973); United States v. DeLeon, 462 F.2d 170 (5th Cir. 1972), cert. denied, 414 U.S. 853 (1973); Fumagalli v. United States, 429 F.2d 10Il (9th Cir. 1970); Ramircz v. United States, 263 F.2d 385 (5tli Cir. 1959); United States v. Connor, 364 F. Supp. 1168 (S.D. Tex. 1973), aff'd, 492 F.2d 1241 (5th Cir. 1974); United States v. Zamora, 364 F. Supp. 1170 (S.D. Tex. 1973).

In Abel v. United States, 362 U.S. 217, 226, 228 (1960), the Court recognized that an administrative search conducted in bad faith would be an impermissible abuse of the administrative search authority, but held that in the absence of proof of such bad faith, the mere potential for abuse would not render the administrative search unconstitutional. The same conclusion has been reached in cases involving anti-hijacking airport searches. See United States v. Skipworth, 482 F.2d 1272 (5th Cir. 1973); United States v. Muelner, 351 F. Supp. 1284 (C.D. Cal. 1972); United States v. Kroll, 351 F. Supp. 148 (W.D. Mo. 1972), aff'd, 481 F.2d 884 (8th Cir. 1973); United States v. Lopez, 328 F. Supp. 1077,1101 (E.D.N.Y. 1971). However, roving alien checks by the border patrol present a particularly difficult situation in which to prove bad faith. Because the searching border patrol agents serve in a dual capacity as both Customs and Immigration officers, they are permitted to "switch hats" in midsearch. See United States v. Thompson, 475 F.2d 1359, 1362 (5th Cir. 1973); United States v. McDaniel, 463 F.2d 129, 134 (5th Cir. 1972). Moreover, if a lesser showing than traditional probable cause is required to authorize alien checks, the standards for Customs searches are in effect simultancously weakened. 
there was a high incidence of illegal alien traffic in the border region. Although the government was attempting to show that relatively few nonaliens would be affected by searches under such conditions, it is by no means clear that all, or even most, people searched will be aliens or alien smugglers. The government did not report the number of innocent citizens whose rights were violated by illegal searches, ${ }^{53}$ nor did it present statistics relating total traffic to total alien traffic by season of the year, time of day, distance from the border, or any other factor that might be relevant. Without such data, Justice Powell should not have uncritically accepted the government's conclusory assertions. 54

The concurrence also reasoned that these searches, because incidental to border protection, share in the extraordinary Fourth Amendment status enjoyed by searches at the border. ${ }^{55}$ In this, the opinion operates at cross-purposes with other judicial attempts to delineate the proper Fourth Amendment standards for searches incidental to border protection. A recurrent problem in such cases has been to determine the permissible distance within the nation's boundaries that the border exception may run. ${ }^{56}$ Instead of helping to define where the border ends and where Fourth Amendment rights attach, the Almeida-Sanchez concurrence will confuse the inquiry by creating a quasi-border lying entirely within the boundaries of the nation.

The concurrence's third reason for finding that random roving alien searches are only modestly intrusive was an assertion that an auto search

53. Some indication is provided by the Brief for Appellec at 25-26, Almeida-Sanchez $v$. United States, 413 U.S. 266 (1973). Nearly two million autos were stopped in 1972, and nearly 400,000 searched thoroughly, to net 39,000 alicns. Thus, approximately 50 cars were stopped, and 10 searched thoroughly, for each alicn found. Moreover, inany aliens enter in groups, assisted by professional alien sinugglers. Id. at 23. Because many of the aliens enter collectively one can only conclude that some inultiple of 50 cars are stopped, and many times 10 are searched, for each alien-bearing velicle found.

54. In any cvent, it appears that the statistical inference called for by the AlmeidaSanchez concurrence would be of dubious reliability. In Camara, the inspections sought to uncover building code violations. Those violations pertained to physical conditions that were fixed and immovable. The only way to eliminate a violation in a target building was to repair it, a result consonant with the aims of inspection. In the case of INS traffic checks, however, enforcement programs have the effect of driving violators out of the enforcement areas. 413 U.S. at 286 (White, J., dissenting). The presence of illegal aliens in a given area may be unrelated to their position at an earlicr time. Although a statistical profile of immigration violations for particular areas might conceivably be constructed for the purpose of obtaining a warrant, the burden of searches later conducted might nevertheless fall primarily on innocent persons.

55. See note 2 supra.

56. See, e.g., United States v. McDaniel, 463 F.2d 129, 132-33 (5th Cir. 1972); Ng Pui Yu v. United States, 352 F.2d 626 (9th Cir. 1965); Murgia v. United States, 285 F.2d 14, 16 (9th Cir. 1960); United States v. Yee Ngee How, 105 F. Supp. 517, 520-21 (N.D. Cal. 1952). Compare United States v. Rodriguez, 195 F. Supp. 513, 516 (S.D. Tex. 1960), aff'd, 292 F.2d 709 (5th Cir. 1961), with United States v. Glaziou, 402 F.2d 8, 12 (2d Cir. 1968), cert. denied, 393 U.S. 1121 (1969). See generally In Search of the Border, supra note 52, at 95,97 . 
entails a lesser invasion of individual privacy than does a search of a person or building. It cited Chambers $v$. Maroney ${ }^{57}$ for the proposition that " $[t]$ his Court "has long distinguished between an automobile and a home or office." "ss Certainly, such a distinction exists, and it is recognized by a separate body of doctrine. However, the Fourth Amendment law on auto searches is not founded on the premise that these searches are inherently less intrusive than other searches; rather, it is based on the pragmatic recognition of the difficulty involved in obtaining a warrant to search a moving car. ${ }^{50}$ Justice Powell, in arguing that a warrant is constitutionally required for a roving alien search, accepted that the special Fourth Amendment doctrine for auto searches was inapposite to the problem at bar. ${ }^{.0}$ To cite Chambers v. Maroney on the degree of intrusiveness of an auto search misapplies the precedent and injects confusion into the legal analysis. The automobile is not a talisman in whose presence the Fourth Amendment vanishes. ${ }^{61}$

The quality of intrusiveness is less related to the place where search occurs than it is to the character of the search itself. ${ }^{22}$ Thus, it is important to examine the nature of the search proposed by the Almeida-Sanchez concurrence.

Camara justifies administrative searches, at least in part, because they impose only a limited intrusion on the individual's Fourth Amendment right of privacy. Typically, in these searches, nothing is seized by the government agents, nor is official suspicion focused on persons. ${ }^{63}$ The inspections are made on a regular, periodic basis and

57. 399 U.S. 42,48 (1970).

58. 413 U.S. at 279 (Powell, J., concurring).

59. See note 16 supra. But see Cardwell v. Lewis, 9.1 S. Ct. 2464 (1974), in which it was stated that an auto search is less intrusive than a search of the home because of the lesser expectation of privacy associated with automobiles. Note that Cardwell cited Justice Powell's concurring opinion in Almeida-Sanchez as cxclusive authority for this statement. Id. at 2469 . Note also that there was only a plurality opinion in Cardwell, so that this view of auto searches does not have majority support. In particular, Justice Powell concurred in the result but did not express any opinion on the degree of intensiveness of auto searches. The four dissenters (per Stewart, J.) reaffirmed the opinion of the Court in Coolidge v. New Hampshire, 403 U.S. 443, 461-62 (1971), that:

The word 'automobile' is not a talisman in whose presence the Fourth Amendment fades away and disappears.

94 S. Ct. at 2473 .

60 . "The very fact that the Government's supporting information relates to criminal activity in certain areas rather than to evidence about a particular automobile renders irrelevant the justification for warrantless searches relied upon by carroll and its progeny." 413 U..S. at 281-82 (Powell, J., concurring).

61. Id. at 269; Coolidge v. New Hampshire, 403 U.S. 443, $461-62$ (1971).

62. "[T]he Fourth Amendment protects people, not places." Katz v. United States, 389 U.S. 347,351 (1967).

63. See La Fave, supra note 28, at 19. 
do not rely on surprise. ${ }^{4}$ The inspectors are not armed officers, and their inspections need not occur outside business hours. ${ }^{65}$

By contrast, a random roving alien search is personal in nature; it is a search of an automobile for information about the car's driver or passengers, rather than for information about the car itself or the condition of its equipment. The searches are conducted day and night by armed, uniformed agents of the federal government. They rely on surprise to trap violators. ${ }^{60}$ The searches are not capable of regular, periodic administration. ${ }^{67}$ In comparison to the building inspections at issue in Camara, roving alien searches do not belong in the category of modestly intrusive administrative search.

Camara's standards for administrative inspections may not properly be applied to the roving alien search in Almeida-Sanchez. Using area search warrants in the context of these INS searches would expand Camara. There is good reason for seeking to limit rather than to extend the application of Camara.

\section{A Critique of Camara}

Camara, like Frank before it, recognized an extraordinary relationship between building code inspections and the Fourth Amendment's protection of personal privacy. The public interest in the prevention and abatement of dangerous or unhealthy conditions in urban dwellings is incontestable. However, the Fourth Amendment's requirement that a warrant be based upon probable cause to search, ${ }^{68}$ and the definition of probable cause in terms of specific information, ${ }^{60}$ threatened to bar the performance of necessary inspections. The response of Frank was to uphold the practice of warrantless building inspections, regarding them as an exception to the Fourth Amendment. Camara's response, on the other hand, was to attempt to fit these searches into the framework of Fourth Amendment law. While the Camara result is arguably the best accommodation of the competing

64. 387 U.S. at 538-39.

65. Id. at 539-40.

66. Brief for Appellee at 25, Almeida-Sanchez v. United States, 413 U.S. 266 (1973).

67. Although the search program might be established on a periodic basis, particular cars obviously would not be searched with any regularity. See note 54 supra.

68. The Fourth Amendment provides that:

The right of the people to be secure in their persons, houses, papers, and effects, against unreasonable searches and seizures, shall not be violated, and no Warrants shall issue, but upon probable cause, supported by Oath or affirmation, and particularly describing the place to be searched, and the persons or things to be seized. U.S. Const, amend. IV.

69. See generally Burnett, Evaluation of Affidavits and Issuance of Search Warrants: A Practical Guide for Federal Magistrates. 64 J. Crim. L. \& Crim'y 270 (1973); Note, Testing the Factual Basis for a Search Warrant, 67 CoLvm. L. Rev. 1529 (1967). 
interests, the Camara opinion is nevertheless problematic. The reasoning of the Court in Camara is internally inconsistent and at variance with traditional Fourth Amendment doctrine. This is not to imply that Camara should be overruled, but only to emphasize that Camara's reasoning, if applied beyond the exceptional facts of that case, may lead to a general erosion of Fourth Amendment standards.

Camara's inconsistency lies in its treatment of the Fourth Amendment's requirement of probable cause. The opinion held that "reasonableness" was the overriding standard of the Fourth Amendment. ${ }^{7 "}$ Moreover, the Court stated:

In cases in which the Fourth Amendment requires that a warrant to search be obtained, 'probable cause' is the standard by which a particular decision to search is tested against the constitutional mandate of reasonableness. ${ }^{71}$

An inspection based on a warrant that did not issue upon probable cause would be unconstitutional, but traditional probable cause could not be demonstrated for building inspections. The Camara solution to this problem was to hold that the conjunction of historical acceptance, need, and limited intrusion rendered these searches "reasonable." 72 Once reasonableness was established, the Court held that probable cause must therefore exist, as if probable cause were a corollary to a finding of reasonableness. ${ }^{73}$ In other words, the Court began by making reasonableness dependent upon probable cause. It concluded by finding probable cause dependent upon reasonableness.

In this inversion of the relationship between probable cause and reasonableness, Camara was internally contradictory and departed from established Fourth Amendment doctrine. As Professor La Fave commented on Camara, "To say that probable cause required by the Fourth Amendment is not a fixed test, but instead involves a sort of calculus incorporating all the surrounding circumstances of the intended search, constitutes a major departure from existing constitutional doctrine." 74

70. 387 U.S. at $528-29$.

71. Id. at $\mathbf{5 3 4}$ (emphasis added).

72. Id. at 537-38.

73. Id. at 538 .

74. La Fave, supra note 28 at 12-13. See Comment, Search and Seizure in the Supreme Court: Shadows On the Fourth Amendment, 28 U. CHI. L. REv. 664, 677 (1961). In Wyman v. James, 400 U.S. 309, 341 (1971), Justice Marshall wrote in dissent that "[o]f course, the Fourth Amendment test is reasonableness, but in determining whether a search is reasonable, this Court is not free merely to balance, in a totally ad hoc fashion, any number of subjective factors." 
In United States v. United States District Court, ${ }^{75}$ Justice Powell wrote that "the definition of reasonableness turns, at least in part, on the more specific commands of the warrant clause."76 In a footnote, he quoted Chimel $v$. Californiait to the effect that finding reasonableness from subjective views regarding the acceptability of certain sorts of police conduct was the kind of unconfined analysis that could eviscerate the Fourth Amendment. ${ }^{78}$ Basically, however, it was this type of analysis that produced Camara.

Camara was a judicial response to an extraordinary conflict of public and private interests, and the decision in that case struck a delicate balance between those interests. ${ }^{79}$ To some extent, however, all Fourth Amendment questions involve the same interests, and the government always presents its case as one of great need. ${ }^{80}$ Unless Camara is limited in its application to searches in which the government's need is equally great, historical acceptance equally strong, and intrusion on personal privacy equally slight, Camara may lead to consequences adverse to the individual's right of privacy. ${ }^{81}$ Adoption of the standards of the Almeida-Sanchez concurrence would misapply Camara and, in so doing, unwisely broaden it.

\section{Conclusion}

The problem of illegal alien traffic is undeniably a serious one, but the way to solve it is not through erosion of the Fourth Amendment. Justice Powell's concurrence in Almeida-Sanchez $v$. United States, by misconstruing Camara v. Municipal Court, constitutes a significant and unjustified departure from Fourth Amendment doctrine.

The roving alien search involved in Almeida-Sanchez does not meet the standards established by Camara for defining the type of search that may be made upon a lesser showing than traditional probable cause. No sufficiently significant history of judicial acceptance exists for

75. 407 U.S. 297 (1972).

76. Id. at 315 .

77. 395 U.S. 752, 764-65 (1969).

78. 407 U.S. at 315 n.15.

79. See generally Greenberg, Balance of Interests Theory and the Fourth Amendment: A Selective Analysis of Supreme Court Action Since Camara and See, 61 Calif. L. Rev. 1011 (1973).

80. See 413 U.S. at 273.

81. See Boyd v. United States, 116 U.S. 616, 635 (1886):

It may be that it is the obnoxious thing in its mildest and least repulsive form; but

illegitimate and unconstitutional practices get their first footing in that way, namely,

by silent approaches and slight deviation from legal modes of procedure. 
these searches, and they are not necessitated by an absence of alternatives. They are personal in nature and aimed at the discovery of evidence of a crime, and thus involve a more than modest intrusion on personal privacy.

If the Camara standard is applied to such searches, there is no rational way to limit the expansion of Camara doctrine. The Camara reasoning was logically flawed and deviated from established Fourth Amendment doctrine. The Fourth Amendment's guarantee against unreasonable searches and seizures would be better served by a narrow construction of Camara than by an expansion of that case to permit the type of search proposed by Justice Powell's concurrence in Almeida-Sanchez. 